\title{
Eco-compensation practice in China's river basins
}

\author{
Chen Genfa ${ }^{1, a}$, Ni Hongzhen ${ }^{2, b}$, Zhang Qiuxia ${ }^{1,2, c}$ \\ ${ }^{1}$ China Institute of Water Resources and Hydropower Research, Beijing, China; \\ ${ }^{2}$ PowerChina Resources Ltd., Beijing, China) \\ achengf02@163.com, bnihongzhen@iwhr.com, czqx815@163.com
}

Keywords: Eco-compensation. Practice. River basins.

Abstract: The eco-compensation mechanism can help alleviate the contradiction between economic-social development and water conservation as well as promote the transformation of economic development mode and the sustained sound development of economic society. In this study, the eco-compensation practices of five typical basins are selected to analyze the eco-compensation characteristics of regional and inter-provincial basins. It is considered that the funds of basin eco-compensation are mainly sourced from the financial funds of governments at all levels, complementary with the support from social donation and special funds. The compensation funds are mainly used for eco-protection construction as well as the prevention and control of water pollution. Meanwhile, the calculation of compensation fund is mainly based on the statistics and monitoring data. Systematical narration is made on the ignored dualization of basin eco-service product existing in the current eco-compensation practice, inadequate attention to the dual nature of compensation subject, insufficient recognition on the duality of compensation object and other problems in this study, so as to provide suggestions for improving the development of basin eco-compensation mechanism.

\section{Research background}

To establish the eco-compensation mechanism of basin upstream and downstream can effectively solve the problems of basin eco-protection and economic coordination [1]. Since the 1980s, based on the eco-compensation theory at home and abroad, the research and application are massively conducted in the eco-compensation connotation, mechanism, evaluation method and practice areas, so as to achieve the unprecedented progresses in both breadth and depth of related theory, method and application [2]. Since the 21st century, China's eco-compensation work has been listed on the schedule step by step. The Central Committee, State Council and various ministries have developed multiple documents about establishing eco-compensation mechanism [3-7] to put forward specific requirements for improving the eco-compensation policy and establishing eco-compensation mechanism, clarify the pilot areas of eco-compensation and propose the goal of complete-coverage important regional eco-compensation. In the past decade, the emphasis degree of eco-compensation has been increasing, and the eco-compensation works in forest, grassland, wetland, water and other key areas have achieved important breakthroughs and progresses.

With overall consideration of multiple factors such as economy, society and ecology, to establish basin eco-compensation mechanism, balance and coordinate the relationship between the upstream and downstream as well as the interests of protectors and beneficiaries, and arouse the enthusiasm of social eco-environment protection are the important contents of national ecological 
civilization system and the necessary measures for comprehensive construction of well-off society and poverty alleviation in China. It is conductive to accelerate the reverse of water eco-environment deterioration trend, gradually realize the "constraint" of water eco-environment consumption and the "incentive" of water eco-environment conservation, alleviate the contradiction between economic-social development and water conservation, and promote the transformation of economic development patterns and the sustainable sound development of economic society.

\section{Analysis on eco-compensation practice in China's basins}

In this study, five practices, i.e., Sanjiangyuan eco-compensation, Xin'an River Basin water environment compensation, Dabie Mountain Area water environment ecological compensation, Dongjiang River Basin eco-compensation and Fujian Minjiang - Jiulong River - Aojiang eco-compensation[8-12], are selected to analyze the crucial factors of eco-compensation such as zoning, capital source, fund use and calculation basis for current China's basin eco-compensation.

\section{Typical eco-compensation practices and areas}

Sanjiangyuan eco-compensation is a comprehensive eco-compensation mechanism, which has been conducted since October 2010 with the implementation areas including 21 counties of four Tibetan autonomous prefectures, i.e., Yushu, Goluo, Huangnan and Hainan, and Tanggulashan Town of Geermu.

The water environment compensation in Xin'an River Basin is China's first pilot project of inter-provincial basin eco-compensation mechanism, which was officially launched in 2011 with the compensation area of the upstream region of Xin'an River Basin. The water environment eco-compensation in Dabie Mountain Area was launched in 2014, and its pattern and management methods are quite similar to Xin'an River eco-compensation.

The Fujian Minjiang - Jiulong River - Aojiang eco-compensation area covers the Minjiang River Basin, the Jiulong River Basin and the Aojiang River Basin in 43 cities and counties, which was implemented in 2015.

Dongjiang River Basin eco-compensation spans Jiangxi and Guangdong provinces, mainly compensating the source area of Dongjiang River Basin, which was launched in 2016.

\section{Compensation fund analysis}

\section{Fund sources and uses}

The current compensation funds are mainly sourced from the governments at all levels (including the Central Government, provincial and municipal governments, etc.), social donations and special funds, which are primarily used for ecological construction, pollution control, people's livelihood improvement and so on, including drinking water source protection, water eco-restoration, soil and water conservation, afforestation protection and other eco-protection and construction measures, as well as water pollution prevention and control measures such as sewage disposal facility construction in urban and rural areas, the livestock and poultry pollution treatment, and the enterprise relocation and transformation for environmental protection. The fund compensation sources and uses for each practice are shown in Table 1. 
Table 1 Fund sources and uses of typical practices in river basin eco-compensation

\begin{tabular}{|c|c|c|}
\hline $\begin{array}{l}\text { River basin } \\
\text { eco-compensation practice }\end{array}$ & Fund source & Fund use \\
\hline $\begin{array}{l}\text { Sanjiangyuan } \\
\text { eco-compensation }\end{array}$ & $\begin{array}{l}\text { Central finance }+ \text { provincial finance }+ \\
\text { appropriate arrangements of prefecture } \\
\text { and county }+ \text { special fund }+ \text { social } \\
\text { donation fund }+ \text { domestic and foreign } \\
\text { carbon sink exchange revenue }\end{array}$ & $\begin{array}{l}\text { (1) Eco-protection and construction } \\
\text { (2) Improvement and upgrading of } \\
\text { basic production and living conditions } \\
\text { and levels of farmers and herders } \\
\text { (3) Upgrading of basic public service } \\
\text { capacity of grass-root government }\end{array}$ \\
\hline $\begin{array}{l}\text { Xin'an River Basin water } \\
\text { environment compensation }\end{array}$ & $\begin{array}{l}\text { Central finance }+ \text { provincial } \\
\text { governmental finance }\end{array}$ & $\begin{array}{l}\text { Water environment protection and water } \\
\text { pollution control }\end{array}$ \\
\hline $\begin{array}{l}\text { Dabie Mountain Area water } \\
\text { environment } \\
\text { eco-compensation }\end{array}$ & $\begin{array}{l}\text { Provincial governmental finance + city } \\
\text { governmental finance }\end{array}$ & $\begin{array}{l}\text { Eco-protection and water pollution } \\
\text { control }\end{array}$ \\
\hline $\begin{array}{l}\text { Fujian Minjiang-Jiulong } \\
\text { River-Aojiang } \\
\text { eco-compensation }\end{array}$ & $\begin{array}{l}\text { Provincial governmental finance }+ \text { city } \\
\text { and county governmental finance }\end{array}$ & Eco-protection and pollution control \\
\hline $\begin{array}{l}\text { Dongjiang Basin } \\
\text { eco-compensation }\end{array}$ & $\begin{array}{l}\text { Provincial governmental finance }+ \\
\text { Central Government reward }\end{array}$ & $\begin{array}{l}\text { Water pollution control and } \\
\text { eco-environmental protection and } \\
\text { construction }\end{array}$ \\
\hline
\end{tabular}

\section{Fund measurement}

The current method of measuring fund is mainly based on statistics or monitoring data, and the weighting method is used to calculate the indexes of fund measurement.

For Sanjiangyuan eco-compensation, fundamental data published by regional statistics department such as population, geographical area, key ecological reserve area and organization setup are used for measurement in combination with the eco-environment monitoring, eco-compensation performance evaluation results and cost difference coefficient. The Dongjiang Basin eco-compensation is determined according to the key index of inter-provincial monitoring cross-section.

The water environment compensations for Xin'an River Basin and Dabie Mountain Area are based on four indexes of permanganate, ammonia nitrogen, total nitrogen and total phosphorus to measure compensation index (see Equation 1).

$$
\mathrm{P}=\mathrm{k}_{0} \times \sum_{i=1}^{4} k_{i} \frac{c_{l}}{C_{i 0}}
$$

In the equation, $\mathbf{k}_{0}$ is water quality stability factor. Considering precipitation runoff and other natural condition change factors, $\mathbf{k}_{0}$ is set as 0.85 .

$\mathbf{k}_{\mathbf{i}}$ is index weight coefficient. According to the average of four indexes, $\mathbf{k}_{\mathbf{i}}$ is set as 0.25 .

$\mathbf{C}_{\mathbf{i}}$ is annual concentration of a certain index.

$\mathbf{C}_{\mathbf{i 0}}$ is basic limit of a certain index.

When annual water quality meets the assessment criteria $(\mathrm{P} \leq 1)$, Zhejiang Province will allocate RMB 100 million yuan to Anhui Province. When the water quality is not up to the assessment criteria (P > 1), Anhui Province will allocate RMB 100 million yuan to Zhejiang Province. Whether in either cases, the Central Government will allocate a finance of RMB 300 million yuan to Anhui province.

The specific gravity method is used for fund measurement in Fujian Minjiang-Jiulong 
River-Aojiang eco-compensation. In this method, water environment comprehensive score factor accounts for $70 \%$ of the weight, measured by border section, the water quality condition of drinking water sources, the completion status of total reduction in water pollutant discharge and key control task. Forest ecological factor accounts for $20 \%$ of the weight, measured by forest coverage and forest accumulation quantity. The control factor of total water consumption accounts for $10 \%$ of the weight, measured by the control target of total water consumption.

\section{Existing problems and suggestions}

In general, the researches and practices of eco-compensation in China's basins have the following problems.

1) The dualization of basin eco-service products is ignored in this study. The main basin eco-service product is water, including water quantity, water quality, time distribution characteristics (flood and drought), the carried sediment and other materials. Basin water cycle is typical of dual nature, including natural water cycle process and artificial side water cycle process, which connects protector and beneficiary. At present, sectional water quantity and quality are widely used as the assessment standard for basin eco-compensation practices, only considering the water eigenvalue in the natural water cycle process rather than the benefit and value of the water in the production activities of human society, so as to rupture the dual characteristic of water as eco-service product.

It is suggested including social and economic benefits of water resources in the accounting basis of eco-compensation standard as an important consideration of fomulating compensation standard and collecting compensation fund, so as to sufficiently distinguish the changes in water resource values of different regions and the resulted differences in compensation standard.

2) The dual characteristic of basin eco-compensation subject has not attracted sufficient attention. The exploitation and utilization of water resources provide support for the downstream social and economic development, and the downstream beneficiaries are one of compensation subjects. Meanwhile, basin water resources play a major role in promoting social stability and ensuring the safety of food and energy. The Central Government and local government are one of the beneficiaries, and basin eco-compensation subject presents the duality. Therefore, in the formulation of compensation mechanism, the downstream beneficiaries should definitely provide compensation funds, and the government as one of the beneficiaries should offer the policy tilt and project support for the protected areas. However, the current China's eco-compensation fund is mainly sourced from the central appropriation or the finance transfer payment between the upstream and downstream governments of the basin, and the specific beneficiaries have not been widely involved. As a result, the problems are caused, such as considerably insufficient compensation fund, deficient actual protector compensation and the decrease of subjective initiative.

It is suggested broadening the compensation fund raising way, using the market and competitive mechanism for the downstream beneficiaries, such as enterprises and residents, paying for basin eco-product consumption, fully enlarging the scale of compensation funds and mobilizing the protector to actively participate in basin ecological protection.

3) The duality of basin eco-compensation object is insufficient. In the basin reserves, people are directly involved in ecological protection, returning farmland to forest, afforestation, fishing ban, animal husbandry limit and other measures, leading to great impacts on their economic foundation and lifestyle, who are undoubtedly compensation objects. But meanwhile, the governments in the reserves also play an unignored role in ecological protection and water conservation, of which the management, promotion and investment intensities make a decisive force in the effect of ecological 
protection and water conservation, so that they are also be compensation objects. Direct compensation of eco-compensation fund to the government, or all direct compensation to the public is one-sided to injure the other party's initiative. At present, eco-compensation funds are mainly compensated to the government in the practice areas, and the government invests in eco-protection project, so that the residents of the protected areas have no direct benefit with the enthusiasm frustrated.

It is suggested developing reasonable the fund proportion of the government and the residents for eco-compensation practices. Part of the fund is used for direct compensation to the residents on the economic loss caused by ecological protection, and another part for the government in eco-protection project implementation and management fees.

\section{Acknowledgements}

This work was financially supported by the Youth Fund of Natural Science Foundation (No.51409271)

\section{Reference}

[1] Zhang Jun. Practice and progress of the basin water environmental eco-compensation in watershed [J] . Environmental Monitoring in China, Vol. 30 No. 1: 191-195

[2] Feng Yanfen, Liu Yihua, Wang Fang et al. Progress of ecological compensation practice in China [J]. Ecological Economy, 2009 (8): 85-88, 105.

[3] The decision to implement the scientific development concept and strengthen environmental protection of State Council, Central Document (2005) No. 39.

http://www.gov.cn/zwgk/2005-12/13/content_125736.htm

[4] Guidance on the pilot work of ecological compensation, State Environmental Protection Administration Document (2007) No. 130. http://www.gov.cn/zwgk/2007-09/14/content_748834.htm

[5] Some views on comprehensively deepening rural reform to accelerate agricultural modernization, http://www.gov.cn/gongbao/content/2014/content_2574736.htm

[6] The view on accelerating the construction of ecological civilization of CPC Central Committee and State Council, http://www.scio.gov.cn/xwfbh/xwbfbh/yg/2/Document/1436286/1436286.htm [7] The view on improving the compensation mechanism for ecological protection of the General Office of State Council, General Office of State Council Document (2016) No. 31. http://www.gov.cn/zhengce/content/2016-05/13/content_5073049.htm [8] Qinghai People's Government Office. Notice on Sanjiangyuan Eco-compensation Mechanism Pilot Method Issued By Qinghai People's Government Office, Gazette of the People's Government of Qinghai Province, Edition 22, 2010.

[9] Pilot implementation scheme of water environment compensation in Xin'an River Basin [10] Water Environment Eco-compensation Method in Dabie Mountain Area, Anhui Province (Finance Department Document (2014) No. 1713.

[11] Eco-compensation Method in Key Basins of Fujian Province, 2015.

[12] Upstream and Downstream lateral eco-compensation agreement in Dongjiang Basin, 2016. 